\title{
Kompozitanyag fejlesztése dinamikus igénybevételre
}

\section{Development of a Composite Material for Impact Load}

\author{
Kovács Tünde Anna, ${ }^{1}$ Nyikes Zoltán, ${ }^{2}$ Figuli Lucia ${ }^{3}$ \\ ${ }^{1}$ Óbudai Egyetem, Bánki Donát Gépész és Biztonságtechnikai Mérnöki kar, Anyagtechnológiai Intézeti \\ Tanszék, Budapest, Magyarország, kovacs.tunde@bgk.uni-obuda.hu \\ ${ }^{2}$ Óbudai Egyetem, Biztonságtudományi Doktori Iskola, Budapest, Magyarország, \\ nyikes.zoltan@phd.uni-obuda.hu \\ ${ }^{3}$ Zsolnai Egyetem, Biztonságtechnikai Mérnöki Kar, Müszaki és Informatikai Tudományok Tanszék, \\ Zsolna, Szlovákia, lucia.figuli@fbi.uniza.sk
}

\begin{abstract}
The goal of this work was to invent a high energy absorbing composite material. This composite needs to be able to attach on the building's surfaces and increase blast-resistance. In this innova-tion, the test samples were reinforced with aramidfiber, glass fiber and carbon fiber and tested by Charpy pendulum impact testing machine. During the tests, the aramid and glass fiber reinforced composites showed good resistance and high energy absorption against impact load.
\end{abstract}

Keywords: composite, impact load, blast-resistant material.

\section{Összefoglalás}

Ebben a dolgozatban nagy energiaelnyelő képességű kompozitanyag kifejlesztése volt a cél, mely a kompozitépületek falazatára szerelve növeli a robbanással szembeni ellenállást. A fejlesztés során aramidszálas, üvegszálas és szénszálas erősítésű próbatestek készültek, melyek vizsgálata Charpy-ütőművel történt. A vizsgálatok során az üveg- és az aramidszálakkal erősített, kerámiaalapú kompozitok mutattak jó ellenálló- és energiaelnyelési képességet ütéssel szemben.

Kulcsszavak: kompozit, dinamikus igénybevétel, robbanásálló anyag.

\section{Bevezetés}

Minden évszázadban találunk fegyvereket és pajzsokat azokban az országokban, amelyeknek szükségük volt ezekre. Az anyagtudomány és technológia fejlődésével a fegyverek és a védelem is fejlődött. Korunkban nemcsak a háború, de a terrorizmus is fenyeget. A terroristamerényletek váratlanul és számos módon következhetnek be. $\mathrm{Az}$ alkalmazott módszerek és robbanóanyagok katasztrófát okozhatnak. A károk enyhítésére (emberélet, épületek, járművek stb.) szükséges a meglévő épületek bevonatokkal történő megerősítése vagy robbanásálló anyagok alkalmazása az építkezéseknél [1-4].

A dinamikus igénybevételek hatására az anya- gok rideg viselkedést mutatnak. Az épületek esetében alkalmazott kerámiatéglák törés közben sok darabra esnek, melyek szétszóródva veszélyt jelentenek. A régi épületek anyagait már nem lehet modern anyagokra cserélni, ezért az utólagos erősítésük megoldást jelenthet [5-9]. Ezzel a módszerrel nem rontanánk a városképet, azonban biztonságosabbá tehetnénk ezeket az épületeket. A falak bevonattal való megerősítésére megfelelő anyagot kell választani. A jelenleg alkalmazott építőipari burkolóanyagok alkalmasak hőszigetelésre, de dinamikus igénybevétel esetén nem nyújtanak védelmet és nem erősítik a falazatot, sőt az alkalmazott hőszigetelő anyagok nagy része tűzveszélyes. 
A kompozit tervezésének legfontosabb része az igénybevétel meghatározása és ebből a feszültségek meghatározása [10-14]. A terhelés alapján lehet a mátrixot és az erősítő elemeket kiválasztani, illetve megfelelőségüket elemezni. Jelenleg igen nagy számú mátrix- és erősítőanyag közül lehet választani. Ezen anyagokból építhető fel megfelelő társítással a meghatározott igénybevételeknek megfelelő kompozit.

Kompozitok tervezéséhez számos tervező rendszer is alkalmazható, melyeknek széles adatbázisuk van, és ezek segítségével mind az anyagválasztás, mind a tervezés egyszerübbé válik.

\section{A kompozit-próbatestek előállítása}

A tervezés során három különböző erősítőanyag állt rendelkezésre (szénszál szövet, üvegszál szövet, aramidszál szövet), melyek tulajdonságai eltérők. A szövetek tulajdonságai a szövés módjától, vagyis a szálak elrendezésétől függenek, azaz irányfüggők. Az alkalmazott erősítőanyagokat az 1-3. ábrák mutatják.

A laminálással készült kompozit-fedőréteg építése során mátrixként epoxigyantát (Araldite LY1564) választottunk. A kompozit tervezése során figyelembe vett anyagok tulajdonságait $\mathrm{az}$ 1. táblázat mutatja.

A kompozithoz egyirányú szálelrendezésű erősítőszövetet használtunk. A próbatestek bemetszés nélküliek voltak. Az elvégzett Charpy-vizsgálat eredményeit az 1. táblázat mutatja [2].

A szakirodalmi ajánlások [2] alapján a kis ütőszilárdságot mutató gyantával impregnált aramidszövetből 6 réteget, míg a nagyobb ütőszilárdságú gyantával impregnált szénszálas és üvegszálas textilekből 4 réteget építettünk a kompozit-fedőrétegbe.

Mivel a cél a jelenleg alkalmazott samotttégla megerősítése volt dinamikus igénybevétellel szemben, ezért a modellkísérletekhez az alsó és a felső lapján epoxigyantába ágyazott erősítőszálakkal laminált samott-téglát (réteges hibrid anyagot) készítettünk a 4. ábrán látható rétegrend szerint.

1. táblázat. Az epoxigyantával impregnált szövetek alkotta kompozitok tulajdonságai [2]

\begin{tabular}{|l|c|c|c|}
\hline & $\begin{array}{c}\text { Üvegszál } \\
\text { szövet }\end{array}$ & $\begin{array}{c}\text { Szénszál } \\
\text { szövet }\end{array}$ & $\begin{array}{c}\text { Aramid- } \\
\text { szál szövet }\end{array}$ \\
\hline $\begin{array}{l}\text { Ütőszilárdság } \\
\left(\mathrm{kJ} / \mathrm{m}^{2}\right)\end{array}$ & 466,2 & 85,7 & 76 \\
\hline $\begin{array}{l}\text { Sürűség } \\
\left(\mathrm{kg} / \mathrm{m}^{3}\right)\end{array}$ & 1900 & 1500 & 1400 \\
\hline
\end{tabular}

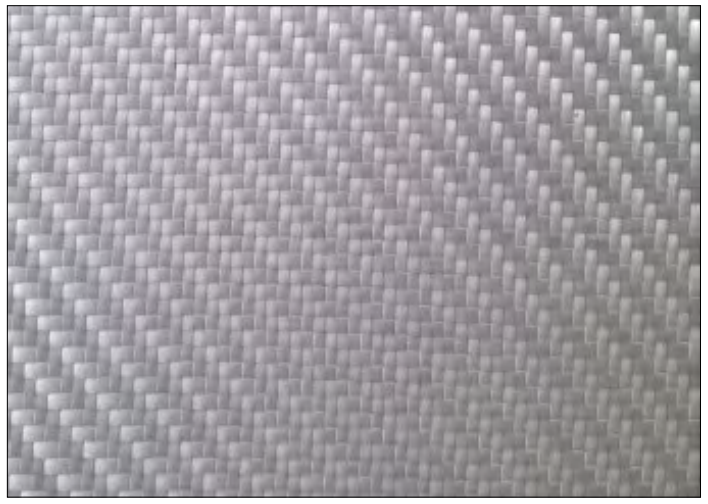

1. ábra. Üvegszál szövet

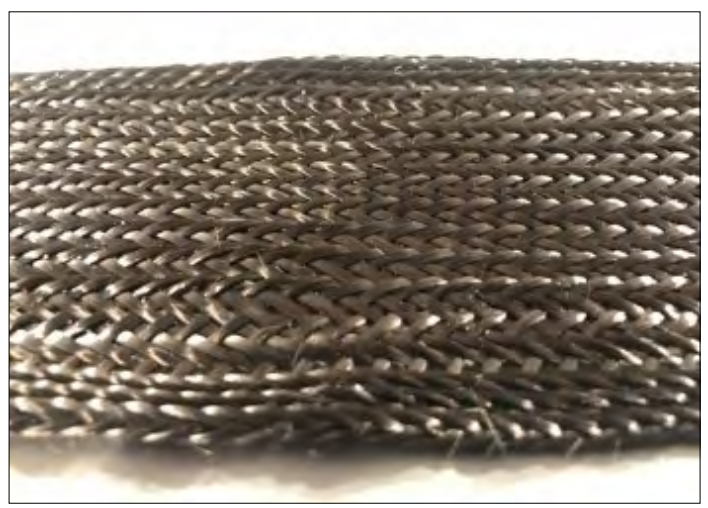

2. ábra. Szénszál szövet

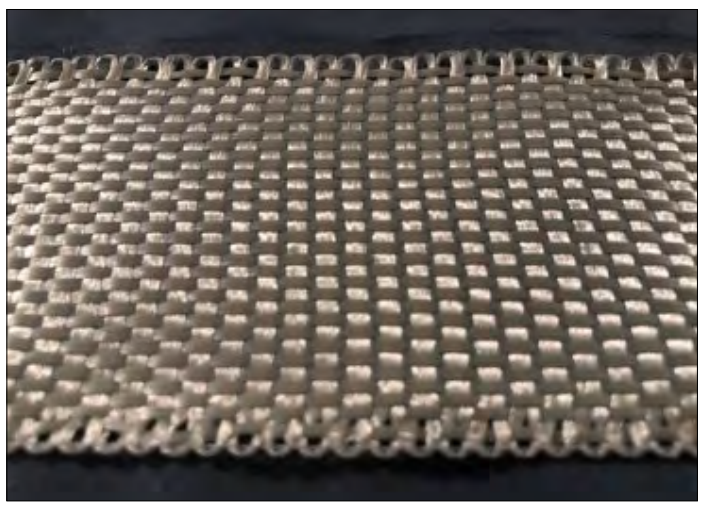

3. ábra. Aramidszál szövet

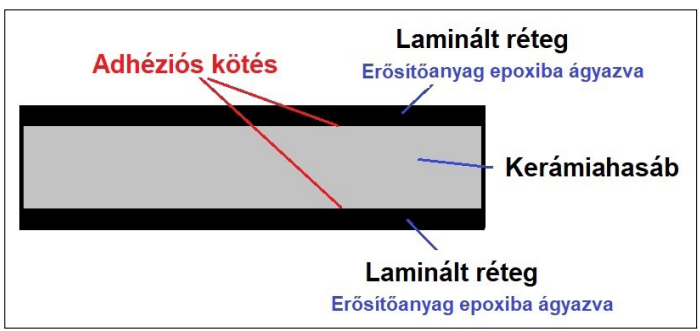

4. ábra. A szendvicspanel felépitése 
Az alkalmazott erősítőanyagok tulajdonságait és a rétegek jellemzőit a 2 . táblázat foglalja össze.

A szendvicsszerkezetű próbatestek gyártása vákuumfúziós módszerrel történt. Az epoxigyanta szilárdulását követően darabolás következett. A próbatestet az anizotrópiája miatt úgy helyeztük el, hogy a dinamikus hatás a laminált felületet érje (5. ábra).

A dinamikus terhelést Charpy-vizsgálattal modelleztük bemetszés nélküli próbatesteken (68. ábrák).

2. táblázat. A kompozithoz alkalmazott erősítőanyagok és rétegjellemzők

\begin{tabular}{|c|c|c|c|}
\hline & Üvegszál & Szénszál & Aramidszál \\
\hline $\begin{array}{c}\text { Szövetjellem- } \\
\text { ző }\left(\mathrm{g} / \mathrm{m}^{2}\right)\end{array}$ & 390 & 480 & 220 \\
\hline Szövés & $\begin{array}{c}2 / 2 \\
\text { sávolyszö- } \\
\text { vés }\end{array}$ & $\begin{array}{c}2 / 2 \\
\text { sávolyszö- } \\
\text { vés }\end{array}$ & $\begin{array}{c}1 / 1 \\
\text { zsákszövés }\end{array}$ \\
\hline Rétegszám & 4 & 4 & 6 \\
\hline Rétegrend & $\left(0_{\mathrm{sz}}\right)_{4}$ & $\left(45_{\mathrm{Sz}}\right)_{4}$ & $\left(0_{\mathrm{Sz}}\right)_{6}$ \\
\hline
\end{tabular}

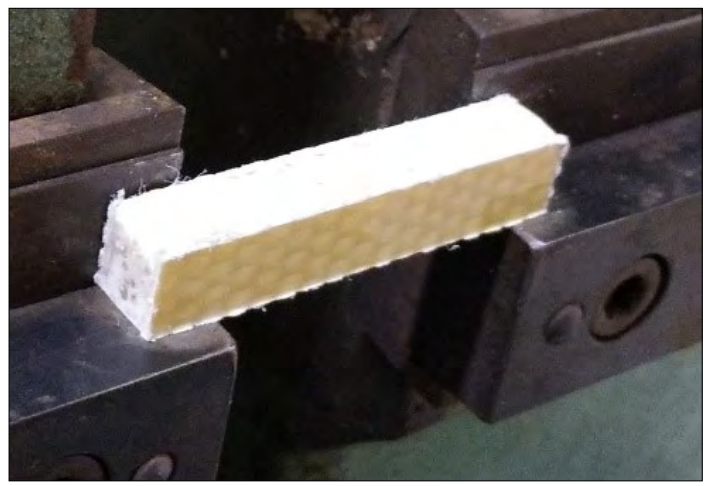

5. ábra. A próbatest elhelyezése a vizsgálat során

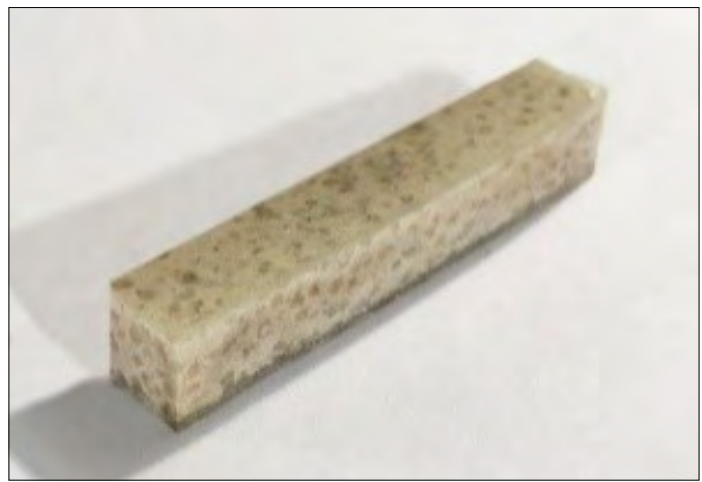

6. ábra. Az üvegszál szövettel és epoxigyantával laminált próbatest képe

\section{Kísérletek}

A próbatesteket Charpy-féle ingás ütőmű berendezésen vizsgáltuk MSZ EN ISO 179-1:2010 szabvány alapján [4]. Az első kísérlet során 1 kg tömegü kalapácsot alkalmaztunk a vizsgálathoz a Charpy-vizsgálathoz $10 \times 10 \times 55 \mathrm{~mm}$ méretű hasábokra.

Az üvegszál szövetes laminálással erősített darabok nem törtek ketté, a kalapács visszapattant, a laminált felületen az ütés nyoma látható (9.ábra).

$\mathrm{Az}$ aramidszál szövetes kompozittal laminált darabok esetén pedig a samottréteg elrepedt, és egyik oldalán a kompozit laminálóréteg levált.

A szénszál szövettel és epoxigyantával laminált próbatestek eltörtek (10. ábra), a kompozit rideg.

3. táblázat. A kísérletek eredményei

\begin{tabular}{|c|c|c|c|}
\hline & $\begin{array}{c}\text { Üvegszál } \\
\text { szövetes }\end{array}$ & $\begin{array}{c}\text { Szénszál } \\
\text { szövetes }\end{array}$ & $\begin{array}{c}\text { Aramidszál } \\
\text { szövetes }\end{array}$ \\
\hline Ütőmunka (J) & 7,3 & 5 & 6,9 \\
\hline $\begin{array}{l}\text { Ütőszilárd- } \\
\text { ság (kJ/m²) }\end{array}$ & 73 & 50 & 69 \\
\hline
\end{tabular}

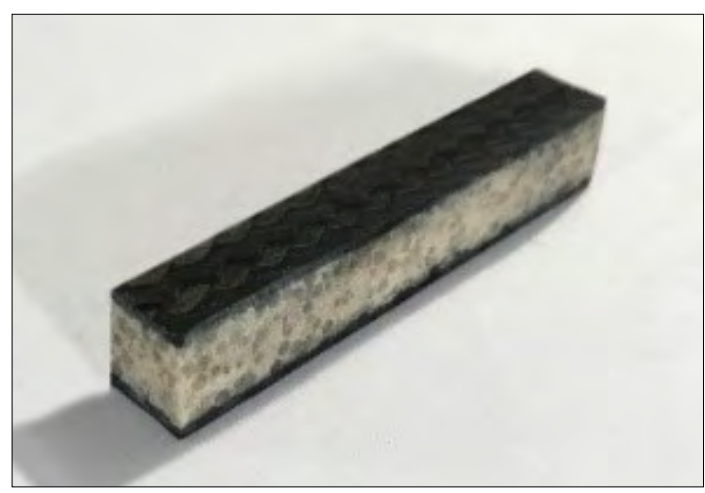

7. ábra. A szénszál szövettel és epoxigyantával laminált próbatest

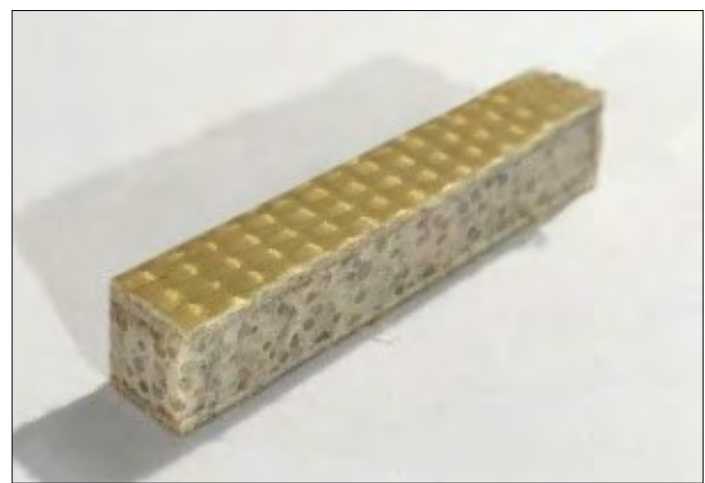

8. ábra. Az aramidszál szövettel és epoxigyantával laminált próbatest 
A kísérleteket megismételtük 30 kg tömegü kalapáccsal, ami már nem adott mérhető értéket, mivel mind a három vizsgált típus eltört, ezért az értékelést a darabok szemrevételezésével végeztük.

\section{Következtetések}

Az üvegszál szövettel és a szénszál szövettel laminált próbatestek a 30 kg-os kalapáccsal végzett kísérletben ridegen törtek és nem mutattak ellenállást (12-13. ábra). Az aramidszál szövettel laminált darabok esetén azonban a darab samott belseje megrepedt, de az aramidszövetes erősítés nem tört el (14. ábra). Az egyik oldalon levált a kerámia felületéről az aramidszövetes laminált réteg, ez azt mutatja, hogy az adhéziós kötés nem volt megfelelő.

Az aramidszövettel laminált próbatestek törése az 1 kg-os és a $30 \mathrm{~kg}$-os kalapács esetén is azonos módon történt, a szendvicspanel nem esett szét, míg az üvegszállal erősített darabok 1 kg-os kala-

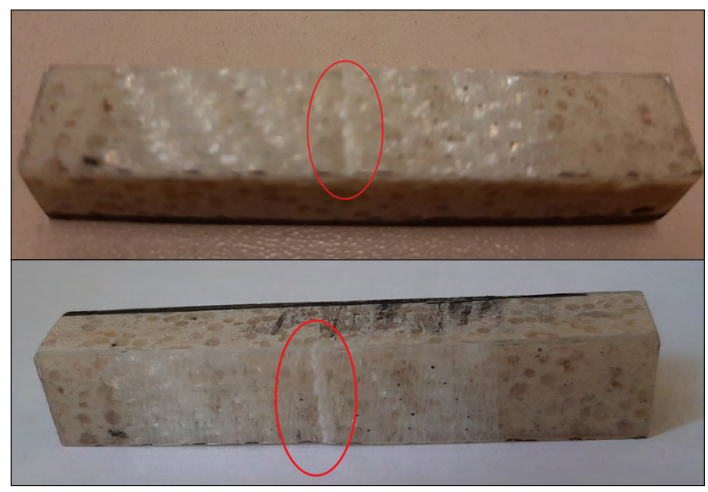

9. ábra. Üvegszövettel laminált próbatest vizsgálat után, a kalapács nyoma jelölve

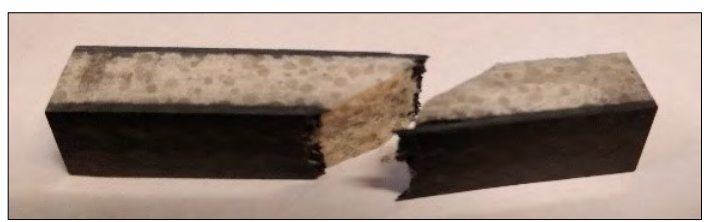

10. ábra. A szénszál szövetes kompozittal laminált próbatest a vizsgálat után

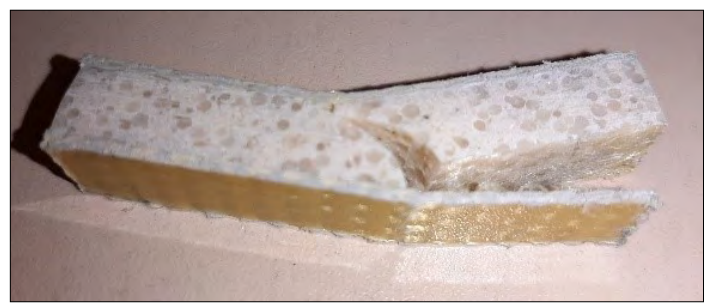

11. ábra. Az aramidszál szövettel és epoxival laminált próbatest a törés után páccsal végzett ütés esetén meg sem repedtek, a 30 kg-os kalapáccsal végzett ütésnél ridegtörést mutattak.

További tervünk a vizsgálatokat $1 \mathrm{~kg}$ és $30 \mathrm{~kg}$ közötti kalapáccsal végezni, hogy kimutatható legyen a határterhelés esete, amit még az üvegszövetes erősítés elvisel. Megállapítható, hogy az aramidszövetes laminált réteg dinamikus igénybevétellel szembeni viselkedése igen jó, az aramid és a samott-tégla közötti adhéziós kapcsolat azonban nem elég erős az alkalmazott epoxigyantával.

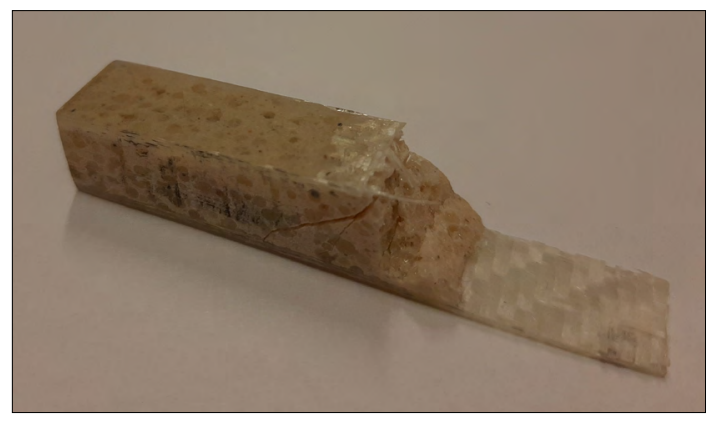

12. ábra. Üvegszövettel és epoxigyantával laminált próbatest

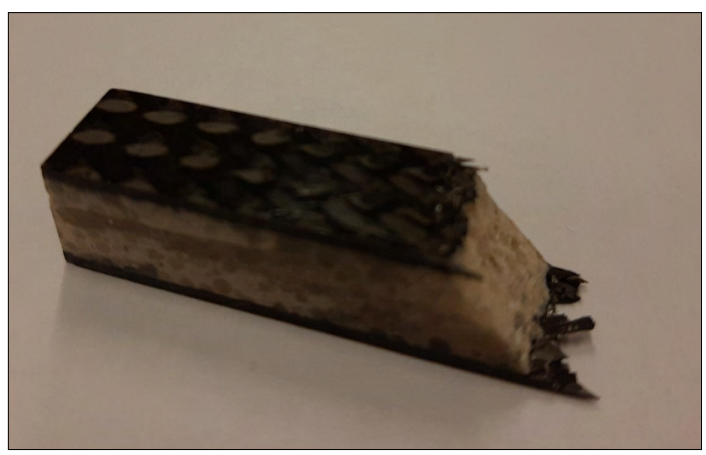

13. ábra. Szénszál szövettel és epoxigyantával laminált próbatest

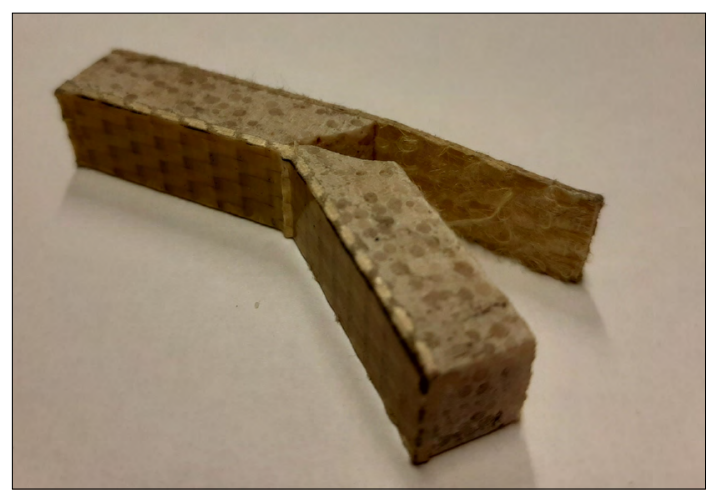

14. ábra. Aramidszövettel és epoxigyantával laminált próbatest a törés után 


\section{Köszönetnyilvánítás}

A szerzők ezúton szeretnének köszönetet mondani a KANDSI Kft. (AKOBEZ) munkatársainak a próbatestek elkészítése során nyújtott technikai segítségért.

\section{Szakirodalmi hivatkozások}

[1] Ashby M. F., Jones D. R. H.: Engineering Materials 1. An Introduction to Properties, Applications and Design. Third Edition, Elsevier Butterworth-Heineman, Cambridge, UK P.K., 2005.

[2] Szakali M., Szücs E.: The defence planning model formation and development / Védelmi tervezésimodellek kialakulása és fejlődése. Hadmérnök, 12/1. (2017) 24-40. ISSN 1788-1919

[3] Malick P. K.: Fiber-reinforces composites. Third edition. Taylor and Francis, Boca Raton, USA, 2008.

[4] Ráthy I., Pinke P., Huszák Cs.: PP mátrixú fröccsöntött kompozitok mechanikai vizsgálatai. Acta Materialia Transylvanica, 1/2. (2018) 105109.

https://doi.org/10.2478/amt-2018-0039

[5] Lange D.: A review of blast loading and explosions in the context of multifunctional buildings. Fire technology SP Technical Research Institut of Sweden 2013. ISSN 0284-5172

[6] Gay E., Berthe L., Boustie M., Arrigoni M., Buzaud E.: Effects of the shock duration on the response of CFRP composite laminates. Journal of Physics D: Applied Physics, 2014 https://doi.org/10.1088/0022-3727/47/45/455303
[7] Zvaková Z., Figuli L., Guttenová D.: Analysis of blast load steel beam. Juniorstav 2014, VUT Brno, ISBN 978-80-214-4851-3.

[8] Figuli L., Jangl Š., Papán D.: Modelling and Testing of Blast Effect On the Structures. IOP Conference Series: Earth and Environmental Science, 44. (5), 052051

https://doi.org/10.1088/1755-1315/44/5/052051

[9] Lu G., Yu T.: Energy absorption of structures and materials. Woodhead Publishing Limited, Cambridge, England 2000.

[10] Qiao P., Yang M., Bobaru F.: Impact Mechanics and High-Energy Absorbing Materials: Review. Journal of Aerospace Engineering, 21/4. (2008) 235-248.

https://doi.org/10.1061/(ASCE)0893-1321 (2008)21:4(235)

[11] Zhou H., Wang X., Ma G.,. Liu Z.: On the effectiveness of blast mitigation with lightweight claddings. Procedia Engineering, 210. (2017) 148-153. https://doi.org/10.1016/j.proeng.2017.11.060

[12] Figuli L., Štaffenová D.: Practical Aspect of Methods Used for Blast Protection. Key Engineering Materials, 755. (2017) 139-146.

https://doi.org/10.4028/www.scientific.net/ KEM.755.139

[13] Daruka N., Kugyela L.: Ipari robbanóanyagok megjelenésének lehetőségei az improvizált robbanószerkezetek kialakításának tekintetében. Robbantástechnika, 35. (2018) 155-174.

[14] Galusca D. G., Galusca L., Tóth L.: Analyses of Deformation of Fibre Reinforced Composits. In: microCAD'98, M Section: International Computer Science Conference. Miskolci Egyetem, 1998. 